\title{
Comparison of Annual Prediction Methods for Spring Flow in the Aggtelek Region
}

\author{
K. Mátyás ${ }^{1}$, K. Bene ${ }^{2}$ \\ ${ }^{1}$ Széchenyi István University, Department of Transport Infrastructure \\ Egyetem tér 1., 9026 Győr, Hungary \\ e-mail: matyas.kevin@sze.hu \\ ${ }^{2}$ Széchenyi István University, Department of Transport Infrastructure \\ Egyetem tér 1., 9026 Győr, Hungary \\ e-mail: benekati@sze.hu
}

Abstract: Karst spring flow plays an increasing important role in groundwater resources in Hungary. This paper evaluates three different estimation methods to predict mean annual spring flows in the Aggtelek region, using GIS based catchment area. Annual spring flow was predicted by two regional regression equations, by applying the Budyko equations, and by the original and modified Maucha method. Using measured spring flows, precipitation and temperature data between 1975-1992 each method was evaluated and compared for 12 spring location in the Aggtelek region. Neither method was found significantly better than the others. The Budyko curves gave a good estimation for annual spring flows, with average variance. The non-linear regression method gave the best result, with the smallest median error, and error variance.

Keywords: Aggtelek; Karst; Hydrology Statistics

\section{Introduction}

Understanding karst aquifers, including management, protection, and spring flow projection poses difficult challenges. There are many methods to investigate and characterize karst systems. They include: water budget, spring discharge hydrograph analyses, precipitation response analyses, deterministic (numerical modelling), lumpedparameters, and fitting statistical models [1]. Meteorological and spring flow measurements were recorded in the Aggtelek region from 1964 to 1995 . This presented a unique opportunity to evaluate several karst modelling approaches to predict karst spring flow. In a previous study, Koch [2] compared the water budget method, lumped numerical models, and neural networks to predict daily, monthly, and annual spring flows. He found that the quantity of recharge changes year by year and is significantly influenced by extreme meteorological and hydrological events, large rainfalls, temperature, and vegetation changes. In an earlier study [3] the Kessler [4], Maucha [5] 
and Willmott [6] methods were applied to predict spring flow using recharge. The three methods gave similar prediction accuracy statistics.

Koch [2] determined that in the Aggtelek region, yearly rainfall data can be used to predict spring flow via linear regression. He used yearly rainfall data starting in July, to predict yearly spring flow starting in October. This method gave a much better estimation for yearly spring discharges $\left(\mathrm{R}^{2}=0.8\right)$ than starting both processes in January. However, these studies raised several more questions.

- $\quad$ can the Maucha method be improved?

- can the linear prediction equation be improved?

- why is it significantly better to use yearly rainfall starting in July, and spring flow starting in October?

- how good is the prediction if only the GIS-based catchment delineation is used?

- $\quad$ is the Budyko method a good alternative to predict yearly spring flows?

\section{Description of the study area}

The Aggtelek-mountain region is an area about $202 \mathrm{~km}^{2}$ located in the northeastern part of Hungary, directly neighboring Slovakia, with karst cover about $70 \mathrm{~km}^{2}$ (Figure 1.). This is a carbonate ridge of the northern Carpathian Mountains. The karst plateaus rise along an east-west direction to an elevation 400-600 $\mathrm{m}$ high. In this region, more than 20 springs can be found with 15 having the most significant discharge. A major portion of the karst is covered by forests containing mainly oak trees and is relatively untouched by development. It is a popular hiking destination with weather moderately cool and wet, and cold winters. The first frost occurs around October 10 and the last about April 25. The yearly rainfall is $600-650 \mathrm{~mm}$ with wet months June, July and August followed by two drier months, September and October. In November and December the precipitation increases slightly. Snow falls for an average 25-40 days and the snow cover remains for $60-80$ days.

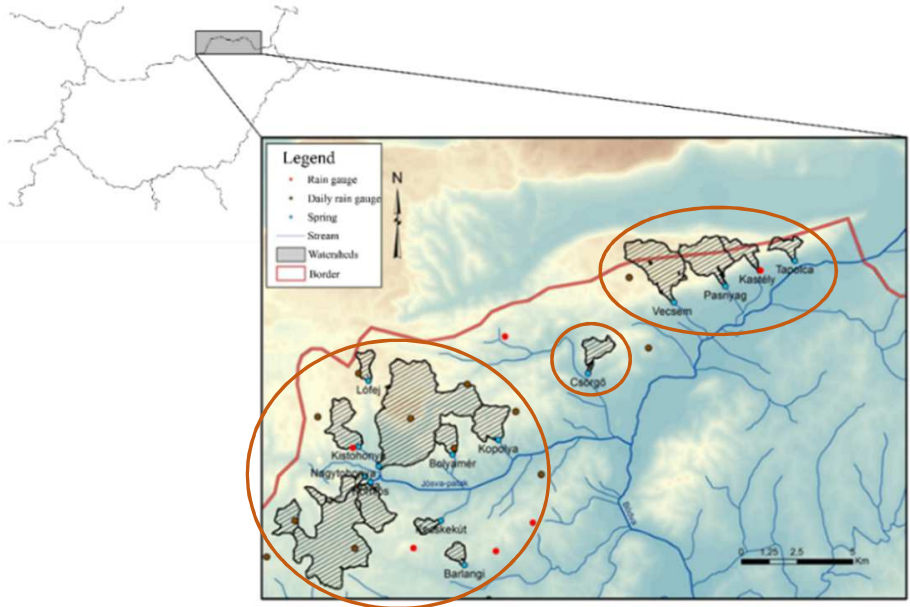

Figure 1. The Aggtelek-karst region. The springs named on the figure were monitored in a previous research (see next chapter) 


\subsection{Measured data}

Research started in the early 1960's to study the surface and subsurface hydrology of the region. The study conducted by the Ferenc Papp Research Station included hydrometeorological measurements, surface flow experiments and analyses, direct and indirect determination of karst infiltration, and water level measurements in karst wells. Additionally, they examined the behavior of springs by analyzing variations of their discharge and physicochemical parameters, such as electrical conductivity, and water temperature. From 1964 to 1995, 15 major springs were monitored and rainfall measurements were collected from rain gauges. The 15 monitored springs can be divided geographically into 3 distinct regions (brown ovals in Figure 1). Springs in the Jósvafó area connect into Jósva creek, except Barlangi spring joins Rét creek, and both creeks discharge into Bódva creek. Upstream on Bódva, the Csörgö and four other springs connect into Bódva stream. Although the catchments were delineated for each spring.

\subsection{Geology}

The primary mass of the mountain is Triassic sediment. The Lower Triassic is a clay and sandstone aquitard, overlain by clayey Middle- and Upper Triassic sediment with carbonaceous dolomite, and limestone. The impermeable Lower Triassic sediment has an overall area of $62 \mathrm{~km}^{2}$, while the limestone-dolomite upper layers are $105 \mathrm{~km}^{2}$. The Southwestern part of the region has a mostly impervious sediment of $35 \mathrm{~km}^{2}$, that contains Pannonian-aged clay, sand, and gravel [7,8]. The majority of the rainfall recharge is carried to the springs through sinkholes and the fracture systems in the karst plateau.

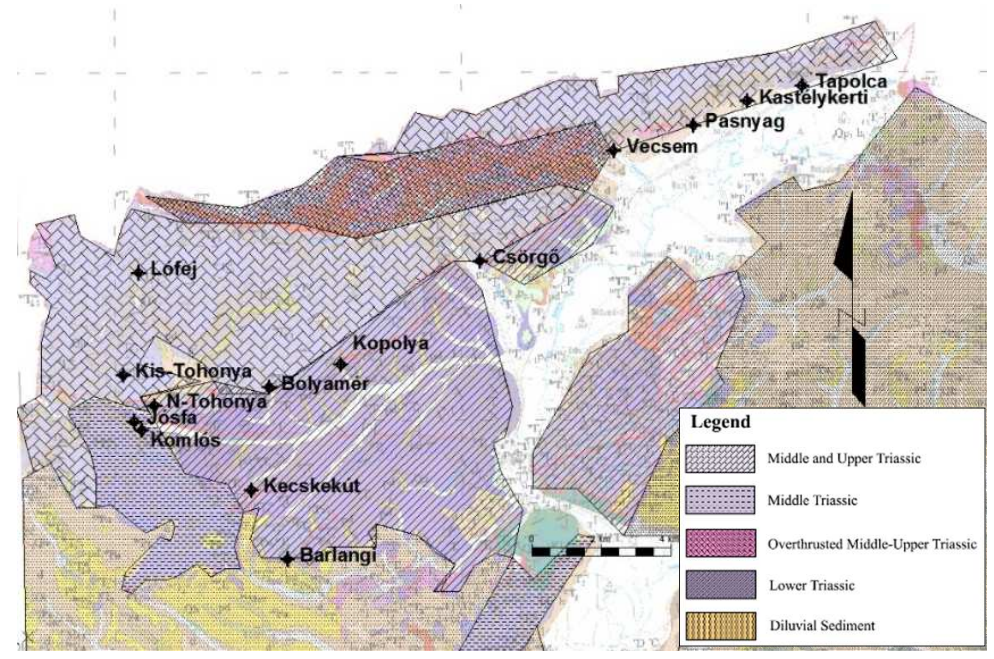

Figure 2. Geological map of the Aggtelek karst [9] 


\section{Time series analyses of spring flows}

From the 15 springs monitored, 12 were selected for analysis. Since the springs were monitored over different lengths of time, a common time range was chosen to properly compare their hydrologic signatures. Table 1 lists the relevant data for each spring. Note that the time series used for analysis was 1974-1989 except Pasnyag. Other data include surface catchment area, mean annual precipitation (MAP), mean annual runoff (MAR), elevation of spring outflow (Meters Above Baltic Sea Level=MASL), latitude (LAT) and longitude (LON).

Table 1. Parameters for the springs

\begin{tabular}{ccccccccc}
\hline $\begin{array}{c}\text { Location } \\
\text { code }\end{array}$ & $\begin{array}{c}\text { Spring } \\
\text { name }\end{array}$ & $\begin{array}{c}\text { Catchment } \\
\text { area }\left(\mathbf{k m}^{2}\right)\end{array}$ & $\begin{array}{c}\text { Analyzed } \\
\text { time series }\end{array}$ & $\begin{array}{c}\text { MAP } \\
(\boldsymbol{m m})\end{array}$ & $\begin{array}{c}\text { MAR } \\
(\boldsymbol{m m})\end{array}$ & MASL & LAT & LON \\
\hline 1 & Bolyamér & 0.97 & $1974-1989$ & 647 & 217 & 268 & 48.492 & 20.595 \\
2 & Csörgő & 1.07 & $1974-1989$ & 659 & 377 & 178 & 48.523 & 20.678 \\
3 & Kastélykerti & 2.95 & $1974-1989$ & 691 & 202 & 167 & 48.563 & 20.787 \\
4 & Kecskekút & 0.52 & $1974-1989$ & 645 & 228 & 245 & 48.464 & 20.587 \\
5 & Kis-Tohonya & 2.04 & $1974-1989$ & 638 & 278 & 258 & 48.496 & 20.538 \\
6 & Komlós & 2.16 & $1974-1989$ & 638 & 162 & 217 & 48.481 & 20.545 \\
7 & Kopolya & 1.99 & $1975-1989$ & 633 & 246 & 220 & 48.497 & 20.623 \\
8 & Lófej & 0.67 & $1974-1989$ & 645 & 260 & 428 & 48.522 & 20.545 \\
9 & Nagy-Tohonya & 12.48 & $1974-1989$ & 638 & 271 & 218 & 48.488 & 20.550 \\
10 & Pasnyag & 5.32 & $1974-1985$ & 720 & 718 & 164 & 48.557 & 20.763 \\
11 & Tapolca & 1.06 & $1974-1989$ & 691 & 206 & 166 & 48.567 & 20.806 \\
12 & Vecsem & 5.06 & $1974-1989$ & 676 & 164 & 189 & 48.551 & 20.731 \\
\hline
\end{tabular}

\subsection{Catchment area}

Determination of spring flow catchment area is more complex in a karst region since many subsurface processes can influence its size. For this study, the area was based on surface geology using GIS delineation. Since most of the annual prediction methods quantify spring flow in $\mathrm{mm} / \mathrm{yr}$ instead of $\mathrm{m}^{3} / \mathrm{s}$, accurate determination of the catchment area improves flow prediction. To assess the reliability of the GIS-measured catchment areas, the hydrologic area of each spring was calculated as well by dividing the annual spring flows $\left(\mathrm{m}^{3} / \mathrm{s}\right)$ by the measured yearly rainfall $(\mathrm{mm})$. The results are shown in Figure 3. Intuitively, catchment area should not change, however climatic factors, or long term changes in catchment characteristics can influence its size. 


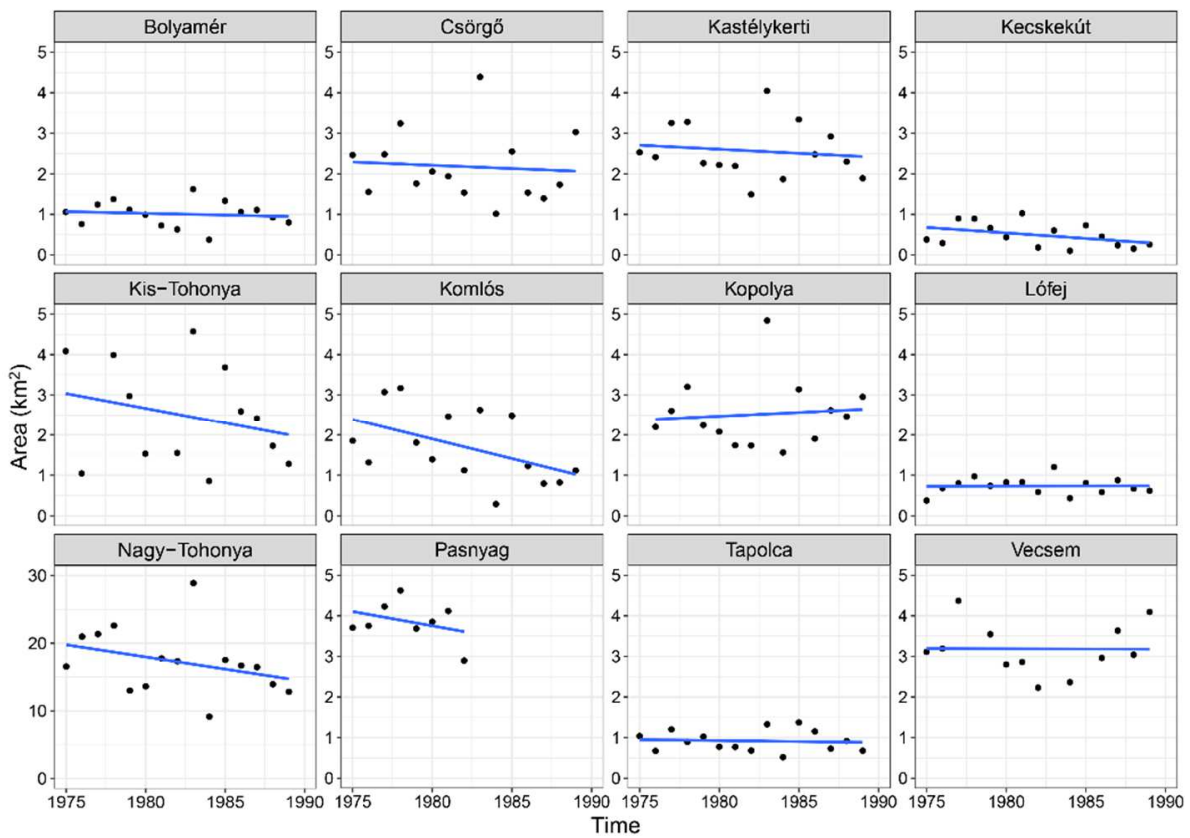

Figure 3. Calculated catchment area $\left(A=\mathrm{km}^{2}\right)$ at each spring, with trend line

Figure 3 illustrates most springs have a wide range of yearly variations. Most of the springs have a declining trend, and only a few shows (Lófej, Bolyamér) no trend. The mean calculated area was determined as well and compared to the measured values. Vecsem had a $40 \%$, Pasnyag 31\% negative difference (GIS overestimations), the rest of the springs had less than $25 \%$ over-under estimation. In this study the GIS-determined areas were used throughout.

\subsection{Parde coefficient}

Yearly distribution of rainfall, temperature, and spring flows were evaluated using the Parde coefficient. The Parde coefficient [10] for spring flow is calculated,

$$
\mathrm{PCV}=\frac{\mathrm{V}_{\mathrm{i}}}{\overline{\mathrm{V}_{12}}}(-)
$$

where $P C V$ is the Parde coefficient of the variables precipitation $P$, flow $Q$ and potential evaporation PET for month $i(-) ; V_{i}$ is the monthly average of variables for month $i$; $\overline{V_{12}}$ is the yearly average of variables for month $i$. The results of the nondimensional comparisons are shown in Figure 4. 

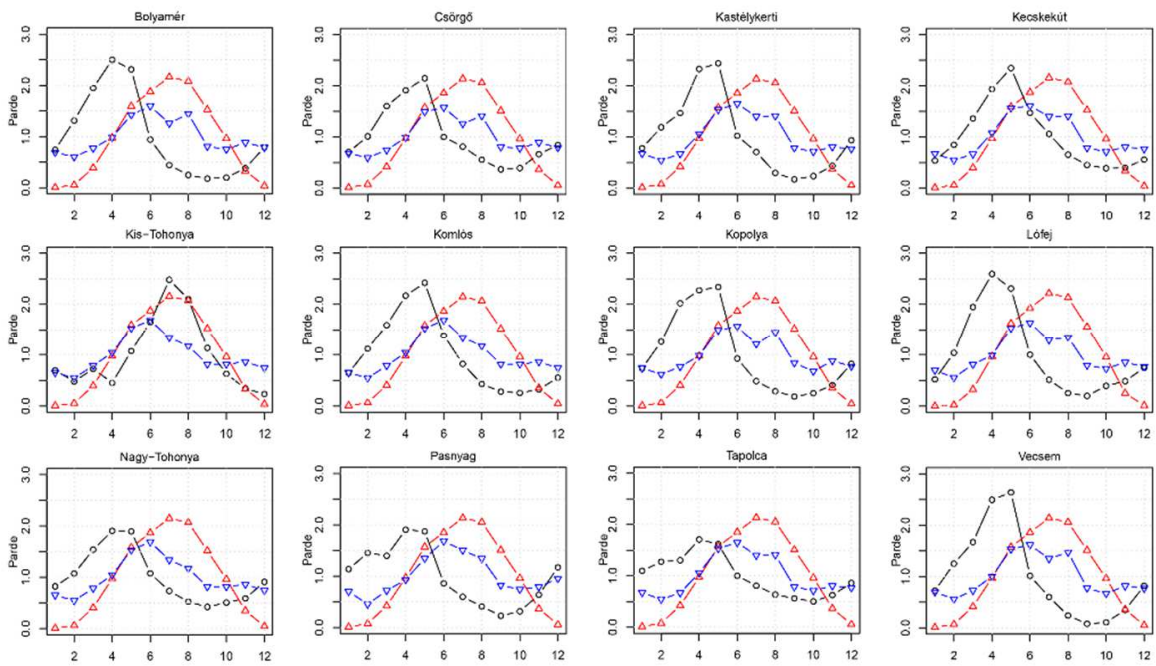

Figure 4. Computed Parde coefficients for each spring

The black lines indicate spring flow, blue lines rainfall, and red lines potential evapotranspiration. The Priestley-Taylor [11] model was used to determine potential evapotranspiration for month $i$,

$$
\mathrm{PET}_{\mathrm{i}}=\sum_{1}^{\mathrm{n}} \alpha_{\mathrm{PT}} \frac{\Delta}{\Delta+\gamma} \frac{\mathrm{R}_{\mathrm{n}}-\mathrm{G}}{\mathrm{L}}(\mathrm{mm} / \mathrm{month})
$$

where $n$ is the number of days in month $i ; \Delta$ is the slope of the saturated vapor pressure graph $\left(\mathrm{kPa} /{ }^{\circ} \mathrm{C}\right) ; \gamma$ is the psychometric constant $\left(\mathrm{kPa} /{ }^{\circ} \mathrm{C}\right) ; R_{n}$ is the available energy on the vegetation covered surface $\left(\mathrm{MJ} / \mathrm{m}^{2}\right.$ day); $G$ is the thermal conductivity of the soil $\left(\mathrm{MJ} / \mathrm{m}^{2}\right.$ day, in this study $G$ was assumed $\left.=0.0\right) ; L$ is the latent heat of vaporization $\left(\mathrm{MJ} / \mathrm{m}^{2} \mathrm{~mm}\right)$ and $\alpha_{P T}$ is the Priestley-Taylor parameter $\left(\alpha_{P T}=1.26\right)[12,13]$.

Monthly distribution of rainfall follows a similar pattern; the spring-summer months are twice as wet as the fall-winter months. Spring flows reach a maximum in April and May, and the karst system drains out in October-November. For some springs, the range between maximum and minimum flows are larger. For example, the maximum flow at the Bolyamér spring in April is twice as much as the minimum flow in October. At the Nagy-Tohonya, Pasnyag, and Tapolca springs, the distribution of flows over the year are much more uniform, indicating a hydrologically different karst system. Comparing rainfall and spring flow in the first 4-4.5 months, there is more spring flow than rainfall and the system is draining. After June, there is more rainfall than spring flow and the karst system is filling. Even when the karst system is filling, spring flows are decreasing until October, indicating a 4-month lag between rainfall and spring flow in the system. If we compare potential evaporation to rainfall at all springs, they are in phase. This reduces recharge during the wet season, and only in the winter months can significant recharge occur. 


\section{Annual spring flow prediction}

There are several methods to predict annual spring flows. The most commonly used methods are: methods based on water budget, and two statistical methods; index methods, and regression methods. From water budget methods, the Maucha method was selected. From the index methods the Budyko method [14] was selected to predict spring flows. Using the Kessler concept (delay in the karst system), a regional regression equation was developed and an attempt to improve the prediction accuracy of spring flows in the Aggtelek region.

\subsection{Maucha method}

Spring discharge $(Q)$ can be determined by multiplying the catchment area $(A)$ with recharge $(R E C H)$. Recharge is the rainfall that infiltrates and recharges the groundwater. It later appears at the spring as discharge. In the Maucha method, yearly recharge $(R E C H)$ is calculated from the water budget components, which include raw recharge $\left(R E C H_{\text {raw }}\right)$, mean precipitation coefficient $\left(P_{c}\right)$, soil water storage coefficient $\left(S_{c}\right)$, potential evapotranspiration coefficient $\left(P E T_{c}\right)$ and surface runoff coefficient $\left(R_{c}\right)$.

$$
\mathrm{RECH}=\mathrm{RECH}_{\mathrm{raw}} \pm \mathrm{P}_{\mathrm{c}} \pm \mathrm{S}_{\mathrm{c}} \pm \mathrm{PET}_{\mathrm{c}}-\mathrm{R}_{\mathrm{c}}(\mathrm{mm} / \mathrm{yr})
$$

The minus sign indicates water movement out of the system. Maucha [5] determined a calculation method for each coefficient. $R E C H_{\text {raw }}$ can be calculated by multiplying the monthly infiltration ratio $(I R)$ with monthly rainfall, and taking the cumulative sum for the whole year.

$$
\mathrm{RECH}_{\text {raw }}=\sum_{\mathrm{i}=1}^{12} \mathrm{IR} \times \mathrm{P}_{\text {mon }}
$$

In this study, a new IR was back-calculated using spring flow data over the same time period.

$$
\mathrm{IR}=\frac{\mathrm{mQ}_{\mathrm{mon}}}{\mathrm{mP}_{\text {mon }}}
$$

where $m Q_{m o n}$ equals mean monthly discharge of every spring for the analyzed time period; $m P_{m o n}$ is mean monthly precipitation at every spring watershed for the analyzed time period. The new $I R$ was calculated by averaging the monthly $I R$ values for every spring. The Maucha and the averaged $I R$ values are shown in Table 2. 
Table 2. IR values for the Aggtelek region

\begin{tabular}{ccc}
\hline Month & IR $_{\text {Maucha }}$ & $\boldsymbol{I R}_{\text {averaged }}$ \\
\hline January & 0.42 & 0.38 \\
February & 0.70 & 0.68 \\
March & 0.68 & 0.73 \\
April & 0.52 & 0.68 \\
May & 0.33 & 0.49 \\
June & 0.16 & 0.24 \\
July & 0.14 & 0.23 \\
August & 0.11 & 0.16 \\
September & 0.13 & 0.17 \\
October & 0.15 & 0.17 \\
November & 0.17 & 0.20 \\
December & 0.30 & 0.34 \\
\hline
\end{tabular}

\subsection{Budyko}

The Budyko method [14] was selected to describe the relationship between climate, vegetation, and the hydrologic cycle. The method expresses the dependence of actual evapotranspiration, AET, on energy availability (usually represented by potential evaporation) and water availability (usually represented by precipitation). Several analytical equations were developed to describe the relationship between the ratio of mean annual actual evaporation to mean annual precipitation and ratio of mean annual potential evaporation and mean annual precipitation. The equations are expressed as a function of the aridity index $\Phi$, the ratio of annual potential evaporation to annual rainfall $(P E T / P)$. Budyko and Fu equations were selected for this study:

$$
\begin{gathered}
\frac{\mathrm{AET}}{\mathrm{P}}=\left[\Phi \tanh (1 / \Phi)\left(1-\exp ^{-\Phi}\right)\right]^{0.5} \\
\frac{\mathrm{AET}}{\mathrm{P}}=1+\Phi-\left(1+\Phi^{\omega}\right)^{\omega} \quad[14](6)
\end{gathered}
$$




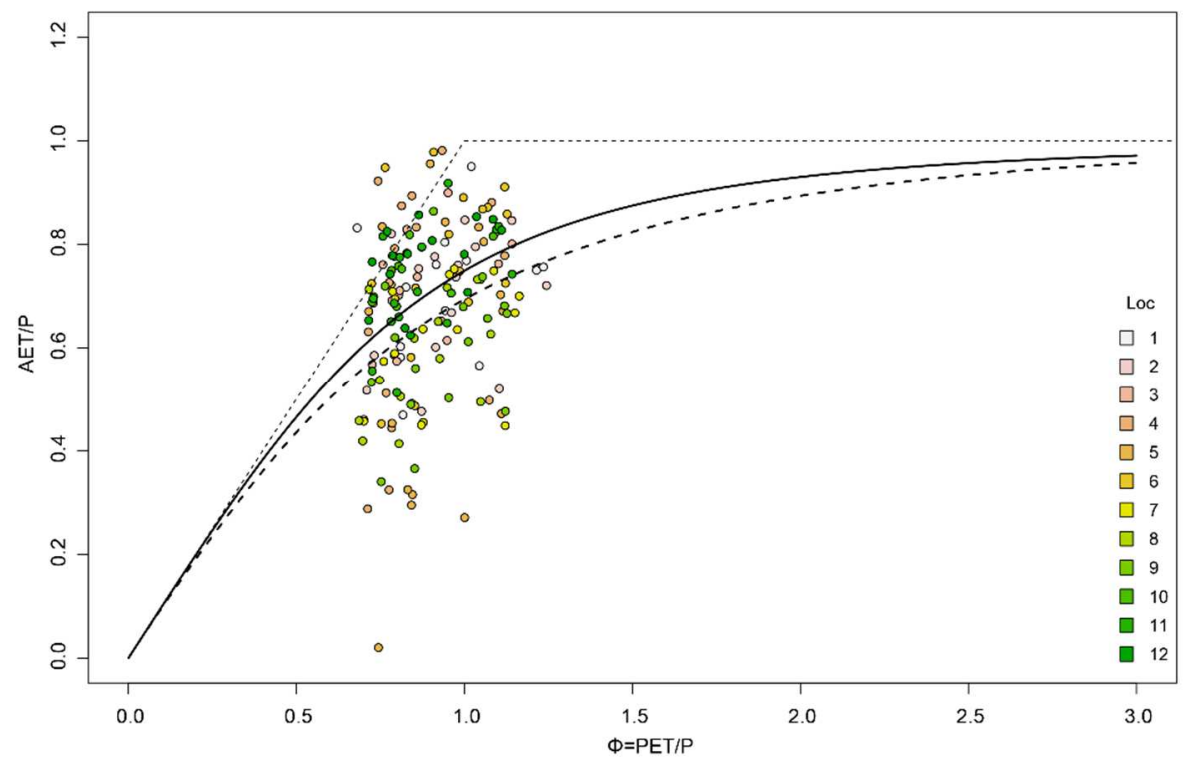

Figure 5. Budyko analysis of the time series of the twelve locations for yearly data (continuous line: Budyko; dashed line: Fu)

Where $\omega$ is a curve-fitting constant. Based on Zhang's [15] research $\omega=2.4$ was assumed. The Priestley-Taylor method (Eq. 2) was used to calculate potential evapotranspiration. In Figure 5 the annual aridity index and the $A E T / P$ ratio was calculated, and plotted for each spring. $A E T$ was determined with the following equation;

$$
\mathrm{AET}=\mathrm{P}-\mathrm{Q}(\mathrm{mm})
$$

Spring locations were color coded to compare variation between spring flows for each year. The aridity index is less than 1 for most years indicating a humid climate, and the hydrological processes are energy limited. For some years the points follow the curve, but many points are above the curve indicating that potential evaporation and precipitation were in phase during the year. Using the Budyko method, spring flow can be calculated by predicting the $A E T / P$ ratio using one of the analytical equations, and the aridity index, then Equation 8 is rearranged to determine spring flow.

\subsection{Regression equation}

In a previous study by Koch [2], it was determined that better regression results can be achieved when the average yearly calculations do not start in January. A crosscorrelation matrix was determined between yearly rainfall $(P)$ and spring flows $(Q)$, with each starting from a different month of the year. The results are shown in Figure 6. The number after the letter indicates the starting month, for example, $P 2$ indicates yearly calculation started in February. 


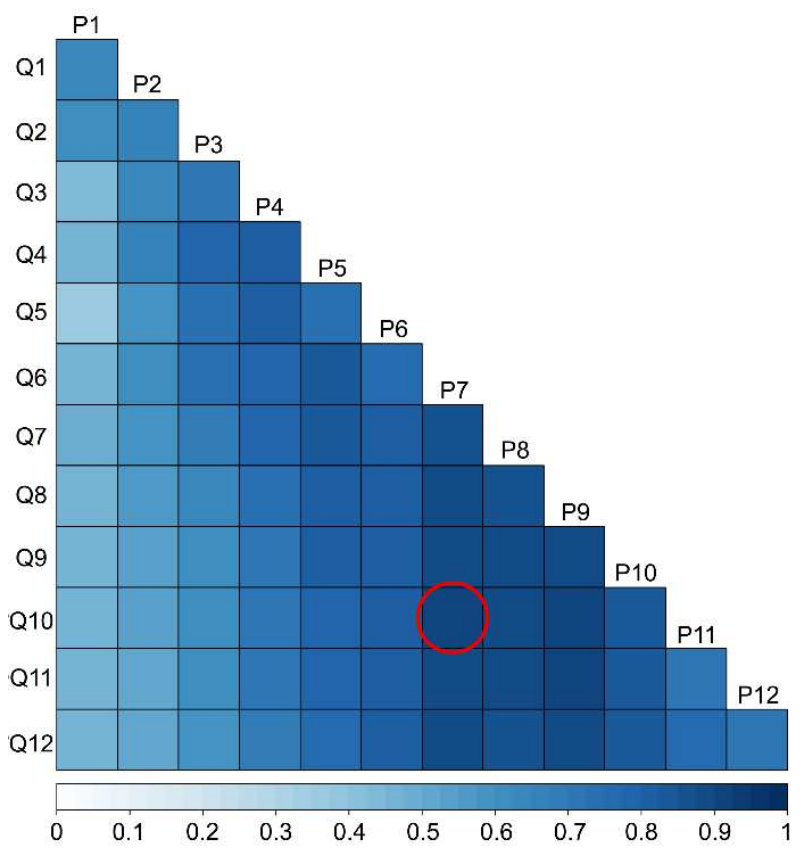

Figure 6. Cross-correlation for spring flow and precipitation

The highest correlations were found when rainfall calculations started in June, July, and August and spring flow calculations started with a 1-3 month delay. The best correlation was found when rainfall calculations started in July and spring flows in November. Using these starting points, a simple a linear regression equation was determined,

$$
\mathrm{Q}_{10}=-402+0.94 \mathrm{P}_{7}(\mathrm{~mm} / \mathrm{yr})
$$

where $Q_{10}$ is the annual flow starting in November. The calculated adjusted $\mathrm{r}^{2}=0.62$. To improve prediction accuracy, several non-linear models were considered, as well as accounting for actual evaporation. The independent predictor precipitation was reduced by actual evapotranspiration $(A E T)$. To estimate mean annual actual evapotranspiration $(A E T)$, the Turc's formula [18] was applied,

$$
\text { AET }=\frac{\mathrm{P}}{\sqrt{\left(0.9+\frac{\mathrm{P}^{2}}{\mathrm{~L}^{2}}\right.}}(\mathrm{mm})
$$

where the value of $L$ depends on the average yearly temperature $\mathrm{t}\left({ }^{\circ} \mathrm{C}\right)$ and can be calculated as:

$$
\mathrm{L}=300+25 \mathrm{t}+0.05 \mathrm{t}^{3}
$$


The method was selected based on its reliability [19] and ease of use. For Hungary, Kovács [20] developed another estimation method to predict actual evapotranspiration. This method will be compared to the Turc method and applied in future studies.

The result of the non-linear regression:

$$
\sqrt{\mathrm{Q}_{10}}=4+0.044\left(\mathrm{P}_{7}-\mathrm{AET}_{7}\right)(\mathrm{mm} / \mathrm{yr})
$$

with $\mathrm{r}^{2}=0.66$. Figure 7 shows the prediction line with the $95 \%$ prediction interval and the test statistics.
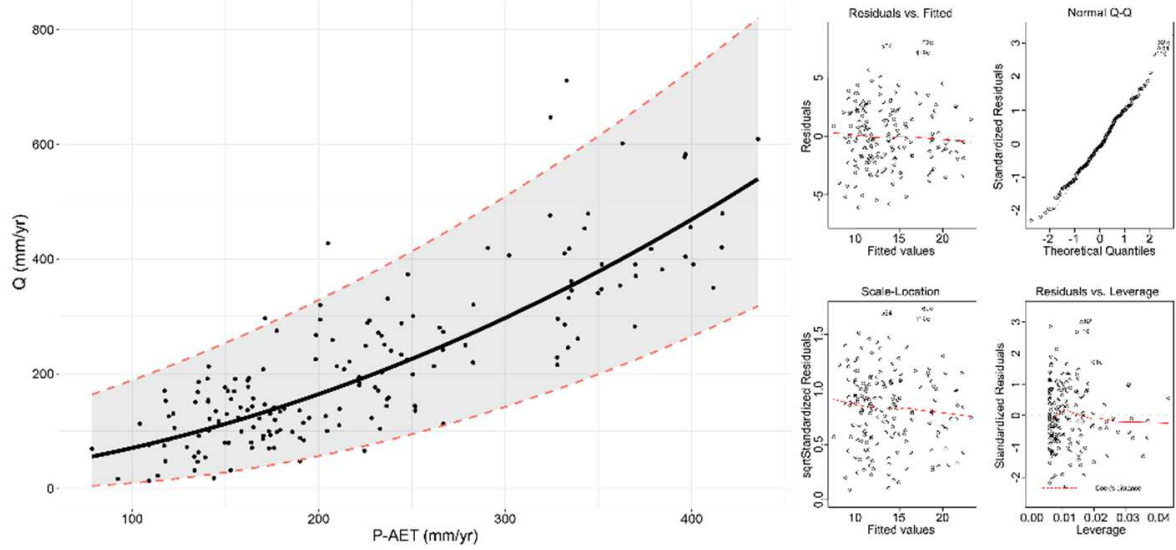

Figure 7. Results of the non-linear statistics

The test statistics are slightly better than determined in several European karst regions [21]. With no rainfall, the predicted spring flow is $16 \mathrm{~mm} / \mathrm{yr}$, resulting in constant base flow at the spring in the Aggtelek region.

\section{Results and discussion}

Three different modelling approaches were compared to predict annual spring flows in the Aggtelek region.

1. A water budget based method. Two variations of the Maucha method were applied: a standard variation (Maucha1) and one using a variable $I R$ parameter shown in (Eq. 5) (Maucha2).

2. An index method. The Budyko curve was used to predict annual spring flows. Budyko1 was the original approach (Eq. 6) while Budyko2 used the Fu method (Eq. 7).

3. A statistical regression method. The first approach (Reg1) used a linear fit (Eq.

9) to the data, while the second (Reg2) used a nonlinear fit (Eq. 12)

To compare the three different modelling methods, the absolute normalized error (ANE) was calculated ( $\mathrm{ANE}=0$ for a perfect prediction), 


$$
\mathrm{ANE}=\left|\frac{\mathrm{Q}_{\mathrm{calc}}-\mathrm{Q}_{\mathrm{m}}}{\mathrm{Q}_{\mathrm{m}}}\right|
$$

where $\mathrm{Q}_{\text {calc }}$ is the calculated spring flow, $\mathrm{Q}_{\mathrm{m}}$ is the measured spring flow. The boxplot of the absolute normalized error distribution of each calculation method is shown in Figure 8.

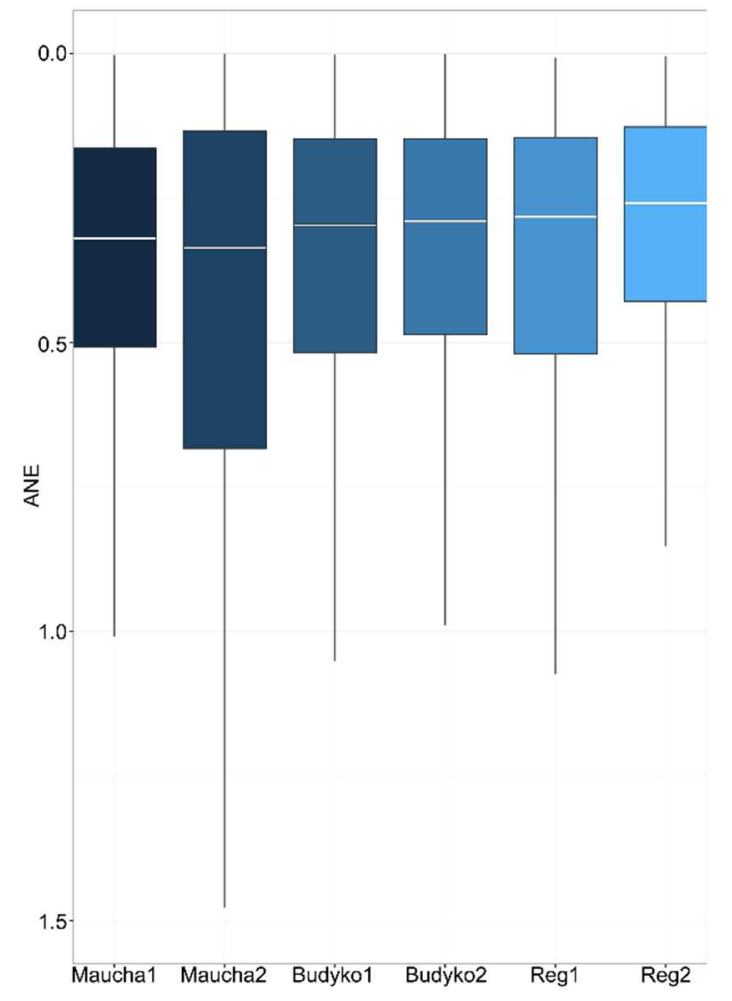

Figure 8. Comparison of 6 annual prediction methods

In Figure 8 the horizontal lines are indicating median errors, the extend of the box represent the $25-75 \%$ percentile of the errors and the upper-lower whisker extends from the hinge to the largest-smallest value no further than $1.5 *$ IQR from the hinge (where IQR is the inter-quartile range, the distance between the first and third quartiles). The median values in Figure 8 are all near 0.3. Median errors are lowest for the Reg2 and Maucha1 methods, while the highest is for the Maucha2 method. The Reg2 method performed best while the Maucha2 method, the worst. It appears that the original IR values are better than newly calculated IR values. The non-linear equation performed better than the linear regression. Catchment characteristics, such as elevation, and size were considered in the regression equations, but no significant correlation was found. If one considers the ease of use, the index methods performed well in comparison to the other methods. Overall the non-linear regression method gave the best prediction errors. 
All methods performed similarly, since the median errors are very close. The more significant difference between the methods are in the overall spread of errors.

In this region, the aridity index is less than one, thus all catchments are energylimited. For these types of catchments, Blöschl [22] showed similar results; in humid regions, the regression methods, and Budyko approach performs similarly. In the Aggtelek region, all methods give satisfactory annual predictions for spring flows. In future studies these predictive methods will be applied to different karst regions in Hungary.

\section{Acknowledgement}

The authors gratefully acknowledge László Maucha and Gábor Izápy for their dedicated 30 years of research and data collection in the Aggtelek karst region.

\section{References}

[1] C. J. Taylor, E. A. Greene: Field Techniques for Estimating Water Fluxes Between Surface Water and Ground Water, in Hydrogeologic Characterization and Methods Used in the Investigation of Karst Hydrology, 2008, pp. 75-111.

[2] R. Koch: Hydrological evluation of Karst-springs, Győr, 2016.

[3] K. Bene, R. Koch, G. Hajnal: Hydrological Study of the Aggtelek Karst Springs, Pollack Periodica, vol. 8, pp. 107-116, 2012.

DOI: http://dx.doi.org/10.1556/Pollack.8.2013.2.12

[4] H. Kessler: Estimation of Subsurface Water Resources in Karstic Regions, IASH II, Toronto, 1957.

[5] L. Maucha: Results and undisturbed data of karsthydrological researches on Aggtelek Hills, Vízgazdálkodási és Kutató Részvénytársaság Hidrológiai Intézete, Budapest, 1998.

[6] C. J. Willmott, C. M. Rowe, Y. Mintz: Climatology of the Terrestrial Reasonal Water Cycle, Journal of Clmyatology, vol. 5, pp. 589-606, 1985. DOI: $10.1002 /$ joc. 3370050602

[7] L. Zámbó: The Aggtelek Karst geomorphological characterization (in Hungarian), Földrajzi Értesítö, vol. 47, no. 3, pp. 359-378, 1998.

[8] M. Veress: Factors influencing solution in karren and on covered karst, Hungarian Geographical Bulletin, vol. 59, no. 3, pp. 289-306, 2010.

[9] L. Gyalog: Explanatory book of the 1:100 000 surface geological map series of Hungary (Magyarázó Magyarország fedett földtani térképéhez 1:100000), Budapest: Magyar Állami Földtani Intézet, 2005.

[10] M. Pardé: Fleuves et rivières, Paris: Armand Colin, 1933.

[11] C. H. B. Priestley, R. J. Taylor: On the Assessment of Surface Heat Flux and Evaporation Using Large-Scale Parameters, Monthly Weather Review, vol. 100, no. 2, pp. 81-92, 1972.

DOI: http://dx.doi.org/10.1175/1520-0493(1972)100<0081:OTAOSH >2.3.CO;2

[12] T. A. McMahon, M. C. Peel, L. Lowe, R. Srikanthan, T. R. McVicar: Estimating actual, potential, reference crop and pan evaporation using standard meterological data: a pragmatic synthesis, Hydrology and Earth System Sciences, no. 17, pp. 1331-1363, 2013. 
DOI: $10.5194 /$ hess-17-1331-2013

[13] L. Y. Rao, G. Sun, C. R. Ford, J. M. Vosemodeling: Potential evapotranspiration of two forested watersheds in the southern Appalachians, American Society of Agricultural and Biological Engineers, vol. 54, no. 6, pp. 2067-2078, 2011. DOI: $10.13031 / 2013.40666$

[14] M. I. Budyko: Climate and Life, Orlando, FL: Academic Press, 1974.

[15] L. K. Zhang, W. Hickel, W. R. Dawes , F. H. S. Chiew , A. W. Western, P. R. Briggs: A rational function approach for estimating mean annual evapotranspiration, Water Resources Research, vol. 40, p. W02502, 2004. DOI: $10.1029 / 2003$ WR002710

[16] B. P. Fu, F. B. P.: On the calculation of the evaporation from land surface [in Chinese], Scientia Atmospherica Sinica, vol. 5, no. 1, pp. 23-31, 1981.

[17] D. Yang, F. Sun, Z. Liu, Z. Cong, G. Ni, Z. Lei: Analyzing spatial and temporal variability of annual water-energy balance in nonhumid regions of China using the Budyko hypothesis, Water Resources Research, vol. 43, p. W04426, 2007. DOI: 10.1029/2006WR005224

[18] L. Turc: Estimation of irrigation water requirements, potential evapotranspiration: a simple climatic formula evolved up to date, Ann. Agron., vol. 12, pp. 13-49, 1961.

[19] J. Parajka, J. Szolgay: Grid-based mapping of long-term mean annual potential and actual evapotranspiration in Slovakia, Hydrology, Water Resources and Ecology in Headwaters, no. 248, pp. 123-129, 1998.

[20] Á. D. Kovács: Specifying lake and areal evapotranspiration rates in Hungary (in Hungarian), Budapesti Müszaki és Gazdaságtudományi Egyetem, Budapest, 2011.

[21] V. Alloca, F. Manna, P. De Vita: Estimating annual groundwater recharge coefficient for karst aquifers of the southern Apennines (Italy), Hydrology and Earth System Sciences, vol. 18, pp. 803-817, 2014.

DOI: $10.5194 /$ hess-18-803-2014

[22] G. Blöschl, M. Sivapalan, T. Wagener, A. Viglione, H. Savenije: Prediction of annual runoff in ungauged basins, in Synthesis across Processes, Places and Scales, Cambridge, Cambridge University Press, 2012, pp. 70-101.

DOI: http://dx.doi.org/10.1017/CBO9781139235761.008 